\title{
Analyzing effective elements in agile supply chain
}

\author{
Babak Jamshidi Navid and Saeid Ismaeli
}

${ }^{a}$ Department of Accounting, Kermanshah Science and Research Branch, Islamic Azad University, Kermanshah, Iran

\begin{tabular}{|c|c|}
\hline A R T I CLE I N F O & A B S T RACT \\
\hline $\begin{array}{l}\text { Article history: } \\
\text { Received April } 25,2011 \\
\text { Received in Revised form } \\
\text { July, } 25,2011 \\
\text { Accepted } 26 \text { July } 2011 \\
\text { Available online } \\
\text { 30 April 2011 }\end{array}$ & $\begin{array}{l}\text { Agile supply chain plays an important role on having efficient production planning. There are } \\
\text { different factors affecting the efficiency of a supply chain and the attempt of this paper is to } \\
\text { find the most important elements in agile supply chain. The proposed model of this paper } \\
\text { gathers decision makers' opinions and based on DEMATEL technique determines the most } \\
\text { important items. The preliminary results of this survey indicate that we could divide the factors } \\
\text { into four groups and two elements including automation and utilization of technical tools of }\end{array}$ \\
\hline
\end{tabular}

Supply chain

Agile supply chain

DEMATEL

Effective factors

(C) 2012 Growing Science Ltd. All rights reserved.

\section{Introduction}

Today, supply chains play important roles in business and there are increasing competition among them (Yusuf et al., 2004). The primary question to address the facts is on how a business succeeds in choosing an appropriate supply chain. A unified and agile supply chain can be a suitable answer for this question. There are different definitions on the concept of agility. Agility was first defined as the ability of an organization in to improve unpredictable and unsteady condition of business (Pandey \& Garg, 2009).

Dove et al. (1991) expressed agility as the ability of administrating and using parts of the necessary knowledge in a firm. Naylor et al. (1999) stated agility as the ability of fulfilling knowledge of market as well as virtual cooperation in creating profitable opportunities in unsteady market. According to Naylor et al. (1999), agility is an advanced ability of business including organizational structures, informative systems and logistic process. The idea of agile originally comes from the flexibility of a supply chain. However, flexibility is not always needed, rather it is accompanied with suitable speed and taking competition. Agility is an important element in reduction of stock, acceptance of market changes effectiveness, powering organization in fast response to customer and combination of more effectiveness of producers.

${ }^{*}$ Corresponding author.

E-mail addresses: babakjamshedy@yahoo.com (B.Jamshidi Navid) 
According Goldman et al. (1995) there are four dimensions associated with agility which are as following:

- Having more customers,

- Cooperation in order to increase competition,

- Organizing in order to focus with changes and untruth,

- Using knowledge of all personals through informative systems.

Agility of a supply chain depends on different factors and these factors may be mutually correlated. Therefore, analysis of these relations is necessary. Cause and effect model plays an important role in agile supply chain. Managers and decision markers can concentrate on more important parts and make suitable decisions by these models. DEMATEL technique can be used in such situations; whereas a total structure of an assessed system is exploited on the basis of relationships among these factors so that influence power and dependency scale of every factor is determined. This research provides relations among effective factors of agility and cause and effect model. In addition, main factors of success are categorized in 4 groups according to influence power and dependency scale.

The principle aims of this article are

- to identify effective factors in agile supply chain,

- to identify relations between these factors by DEMATEL technique,

- to provide cause and effect model from recognized key factors,

- and to categorize factors based on influence power and dependency scale of every one of factors.

\section{Key factors in agile supply chain}

For the proposed model of this paper, 10 effective factors in agile supply chain were identified on the basis of reviewing previous researches and reception of expert's opinions. Table 2 summarizes the summary of these 10 factors.

Table 1

Effective factors in agile supply chain

\begin{tabular}{|c|c|c|}
\hline Symbol & Factor & Source \\
\hline F1 & Automation & Goldman et al., 1995; Pandey \& Garg, 2009; \\
\hline $\mathrm{F} 2$ & $\begin{array}{l}\text { Relations of Customer and } \\
\text { distributor; trust }\end{array}$ & $\begin{array}{l}\text { Simchi-Levi et al., 2008; Fliedner,2003; Bultema, 2000; } \\
\text { Agarwal \& Shankar, } 2003\end{array}$ \\
\hline F3 & $\begin{array}{l}\text { Programming, Forecasting and } \\
\text { Cooperative Preparations }\end{array}$ & Yusuf et al., 2004; Pandey, \& Garg, 2009; Fliedner, 2003 \\
\hline F4 & Unification of processes & $\begin{array}{l}\text { Pandey \& Garg, 2009; Mason-Jones \& Towill, 1999; } \\
\text { Agarwal \& Shankar, 2003 }\end{array}$ \\
\hline F5 & $\begin{array}{l}\text { using technical informative and } \\
\text { communicative tools }\end{array}$ & $\begin{array}{l}\text { Pandey \& Garg, 2009; Mason-Jones \& Towill, 1999; } \\
\text { Agarwal \& Shankar, } 2003\end{array}$ \\
\hline F6 & Process of on time production & Goldman et al., 1995; Milgate, 2011 \\
\hline F7 & $\begin{array}{l}\text { Preparation for focusing } \\
\text { unsteady market }\end{array}$ & Pandey \& Garg, 2009; Marshall et al., 2004 \\
\hline F8 & Cost reduction & $\begin{array}{l}\text { Pandey \& Garg, 2009; Fliedner, 2003; Kumar \& Brittain, } \\
\text { 1995; Shekari et al., 2011; Cheshmberah et al., } 2011\end{array}$ \\
\hline F9 & Improvement of quality & Kumar \& Brittain, 1995; Yasin, 2004 \\
\hline F10 & customer's satisfaction & $\begin{array}{l}\text { Yasin, 2004; Jharkharia, S., \& Shankar, 2004; Ravi, 2005; } \\
\text { Chan, 2002; Rafeie rad et al., } 2011\end{array}$ \\
\hline
\end{tabular}




\subsection{Automation}

Automation can be defined as a replacement of manual operation by computer methods, so that, all operations must be done with a minimum human power. Principle changes in automation bring about increasing flexibility, variability, and quality of production processes (Goldman et al., 1995). Automation is important in productive process and administrative centers in supply chain equality. There are several software packages of automation, which are used to control machines and other computerized instruments in productive process. Flexible productive systems, simultaneous engineering, cooperative engineering and alert production are among new concept associated with productive automation, so that every one of these concepts attends more for agility of production. Administrative automation refers to combination of official operations including correspondence, recording and timing administrative programs. Some of automation tools are as followed: PC, laser printer, copy machines, Fax, scanner and digital Cameras (Pandey \& Garg, 2009).

\subsection{Relationships between customers and distributors; Trust}

If there are steady relations and trust among customers and sellers, transactions will be utilized more quickly and efficiently as long as there will a good trust between both parties. A mutual trust decreases transaction times, which yields faster exchange of money and goods in supply chain (Simchi-Levi et al., 2008; Fliedner, 2003). Respecting customer brings more trueness and attraction to competitors' services. Today, most of the companies review their relationships with customers, and try to improve their relations and long time communication with customers and their trueness (Bultema, 2000; Agarwal \& Shankar, 2003).

\subsection{Planning, forecasting and cooperative preparations}

Planning, forecasting and cooperative preparations are web based operations including planning production and inventory, prediction of demand, insurance of supply among commercial partners and these operation play important role on agility (Fliedner, 2003). In fact, the primary objective of planning is to distribute information through web to insure chain in long time. These processes are designed to improve transactions from sellers to final customers. The other objective is to design web based facilities to identify any possible error in prediction and ordering inventories to prevent any negative impact on profitability (Pandey \& Garg, 2009).

\subsection{Unification of processes}

Supply chain consists of different subsystems; and each subsystem is a part of total commercial processes. For example, process of delivery and an order provision may be needed for the cooperation of management system of communication with customer, inventory and transportation system, and one or more accounting systems. If all these systems are unified, all processes can be automatically completed, and this case causes more effective business (Mason-Jones \& Towill, 1999). The main benefit of unifying process is flexibility increase so that different system combinations could be executed. In a supply chain, combination of processes is occurred through cooperation among customers and suppliers. This causes to improve common production, cooperative system design and information division (Pandey \& Garg, 2009; Agarwal \& Shankar, 2003).

\subsection{Using information and technical tools relationship}

Different tools are designed to secure needs in all stages of supply chain. These software packages are operated more precisely. Faster transmission of information results in more agility in supply 
chain. Using internet, intranet, electronic transmission and other technologies can connect all parts of supply chain to expedite the operations (Mason-Jones \& Towill, 1999; Agarwal \&Shankar, 2003).

\subsection{In time Production system}

Organizations or companies can improve their profitability by decreasing inventory level, eliminating wastages, decreasing waiting and transporting time, reducing errors and make shorter time for return of capital. Kanban system is one of the basic factors in just-in-time production emphasizing on tensional system. Kanban system includes different information such as section, name and number, place of source and destination (Simchi-Levi et al., 2008). Milgate (2001) discussed Kanban system and their applications and stated that this system could play an important role on unifying all partners of supply chain.

\subsection{Preparation for focusing unsteady market}

Some of effective factors on unsteady market involve sensitivity and potential of market as well as strength of competition. Sensitivity of market refers to demand and price fluctuations. An agile supply chain can overcome on demand fluctuations. Achievement of knowledge and experiences in the field of these variables can be suitably based on comprehending unsteady market (Pandey \& Garg, 2009; Marshall et al., 2004).

\subsection{Cost reduction}

Cost reduction is one the most important needs in modern life. Cost reduction plays an important role on companies operating in developing countries. There are different strategies for cost reduction, which includes design, appropriate production plan by decreasing wastage, in time production, Kanban and tensional production systems, etc. (Pandey \& Garg, 2009; Fliedner, 2003; Kumar \& Brittain, 1995).

\subsection{Quality improvement}

Quality improvement is another component, which plays an important role on increasing company's productivity. There are different techniques, which could be used for increasing the productivity of a production system from design perspectives to customer supplement (Kumar \& Brittain, 1995; Yasin et al., 2004).

\subsection{Customer's satisfaction}

Customer satisfaction is the ultimate objective of any firm and this could be studied in three divisions of prior to transaction, during transaction and after transaction. There are different factors affecting customer satisfaction such as logistic factors, marketing, etc (Ravi \& Shankar, 2005; Chan, 2002).

\section{DEMATEL technique}

This technique is a comprehensive method, which could analyze complex relationships in a system. In this method, a collection of effective variables on system are organized in cause and effect diagram. Using DEMATEL technique, managers and researchers will be able to comprehend relationships among variables and it has been used in different studies, which are shown in Table 2. 
Table 2

Some of utilization cases of DEMATEL technique

Author Field of usage

Abbaszadeh et al., 2010

Establishment of knowledge management

Jamali et al., 2010

Shieh et al., 2010

Establishment of quality management

Ho et al., 2010

Evaluation of quality of services in hospital

Tsai \& Chou, 2009

Selection of stock

Wu, 2008

Selection of management systems

Selection of knowledge management strategies

Process of DEMATEL usage is shown in Fig. 1.

\subsection{Calculation of average matrix}

In our survey, we first investigate the relationship between different variables based on some decision makers' opinions. The opinion gathers based on Likert scale where zero indicates ineffective element, 1 represents little impact, 2 shows average and 3 is used for high effect. In our survey, thirteen people participated in our survey and the results of our survey are shown in Table 3.

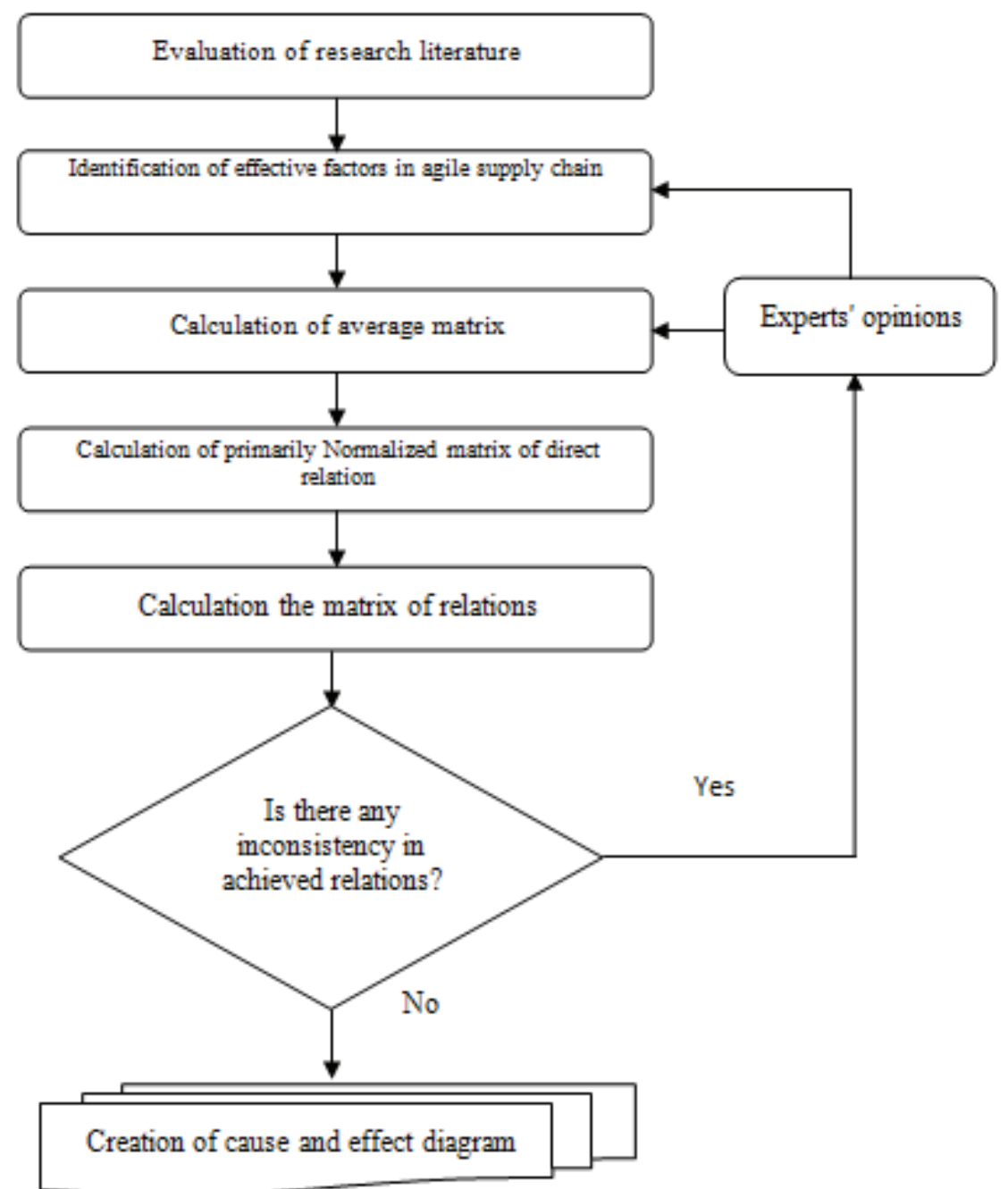

Fig. 1. Process of drawing cause and effect 
Table 3

Average matrix

\begin{tabular}{|c|c|c|c|c|c|c|c|c|c|c|}
\hline Factor & $F_{1}$ & $\mathrm{~F}_{2}$ & $\mathrm{~F}_{3}$ & $F_{4}$ & $\mathrm{~F}_{5}$ & $F_{6}$ & $\mathrm{~F}_{7}$ & $\mathrm{~F}_{8}$ & $\mathrm{~F}_{9}$ & $F_{10}$ \\
\hline $\mathrm{F}_{1}$ & 0.000 & 0.000 & 2.541 & 2.878 & 2.950 & 1.781 & 1.852 & 2.541 & 2.531 & 1.342 \\
\hline $\mathrm{F}_{2}$ & 0.000 & 0.000 & 2.672 & 0.000 & 0.000 & 0.000 & 0.000 & 1.562 & 0.000 & 1.873 \\
\hline $\mathrm{F}_{3}$ & 0.000 & 2.423 & 0.000 & 2.830 & 0.000 & 2.525 & 1.320 & 2.541 & 2.531 & 1.976 \\
\hline $\mathrm{F}_{4}$ & 0.000 & 2.536 & 3.000 & 0.000 & 0.000 & 2.056 & 0.000 & 2.650 & 2.980 & 1.876 \\
\hline $\mathrm{F}_{5}$ & 2.635 & 1.932 & 2.635 & 2.736 & 0.000 & 1.832 & 2.635 & 2.673 & 2.543 & 1.833 \\
\hline $\mathrm{F}_{6}$ & 0.000 & 1.535 & 2.726 & 2.535 & 0.000 & 0.000 & 1.312 & 1.762 & 2.973 & 1.822 \\
\hline $\mathrm{F}_{7}$ & 0.000 & 2.626 & 2.251 & 1.621 & 0.000 & 1.722 & 0.000 & 1.720 & 1.675 & 1.630 \\
\hline $\mathrm{F}_{8}$ & 0.000 & 1.321 & 0.000 & 0.000 & 0.000 & 0.000 & 0.000 & 0.000 & 0.000 & 3.000 \\
\hline $\mathrm{F}_{9}$ & 0.000 & 2.435 & 0.000 & 2.543 & 0.000 & 0.000 & 0.000 & 0.000 & 0.000 & 3.000 \\
\hline$F_{10}$ & 0.000 & 2.422 & 0.000 & 0.000 & 0.000 & 0.000 & 0.000 & 0.000 & 0.000 & 0.000 \\
\hline
\end{tabular}

\subsection{Calculation of primarily normalized matrix of direct relation}

Based on average matrix and using Eq. (1) and Eq. (2) primarily normalized matrix of direct relations was obtained. This matrix is shown in Table 4.

$$
\begin{aligned}
& M=k \cdot A \\
& k=\frac{1}{\max _{1 \leq i \leq n} \sum_{j=1}^{n} a_{i j}} \quad, i, j=1,2, \ldots, n
\end{aligned}
$$

where $a_{i j}$ shows scale of effect in element $i$ on $j$.

Table 4

\begin{tabular}{|c|c|c|c|c|c|c|c|c|c|c|}
\hline Factor & $\mathrm{F}_{1}$ & $\mathrm{~F}_{2}$ & $\mathrm{~F}_{3}$ & $\mathrm{~F}_{4}$ & $\mathrm{~F}_{5}$ & $\mathrm{~F}_{6}$ & $\mathrm{~F}_{7}$ & $\mathrm{~F}_{8}$ & $\mathrm{~F}_{9}$ & $\mathrm{~F}_{10}$ \\
\hline $\mathrm{F}_{1}$ & 0.000 & 0.000 & 0.118 & 0.134 & 0.138 & 0.083 & 0.086 & 0.118 & 0.118 & 0.063 \\
\hline $\mathrm{F}_{2}$ & 0.000 & 0.000 & 0.125 & 0.000 & 0.000 & 0.000 & 0.000 & 0.073 & 0.000 & 0.087 \\
\hline $\mathrm{F}_{3}$ & 0.000 & 0.113 & 0.000 & 0.132 & 0.000 & 0.118 & 0.062 & 0.118 & 0.118 & 0.092 \\
\hline $\mathrm{F}_{4}$ & 0.000 & 0.118 & 0.140 & 0.000 & 0.000 & 0.096 & 0.000 & 0.124 & 0.139 & 0.087 \\
\hline $\mathrm{F}_{5}$ & 0.123 & 0.090 & 0.123 & 0.128 & 0.000 & 0.085 & 0.123 & 0.125 & 0.119 & 0.085 \\
\hline $\mathrm{F}_{6}$ & 0.000 & 0.072 & 0.127 & 0.118 & 0.000 & 0.000 & 0.061 & 0.082 & 0.139 & 0.085 \\
\hline $\mathrm{F}_{7}$ & 0.000 & 0.122 & 0.105 & 0.076 & 0.000 & 0.080 & 0.000 & 0.080 & 0.078 & 0.076 \\
\hline $\mathrm{F}_{8}$ & 0.000 & 0.062 & 0.000 & 0.000 & 0.000 & 0.000 & 0.000 & 0.000 & 0.000 & 0.140 \\
\hline $\mathrm{F}_{9}$ & 0.000 & 0.113 & 0.000 & 0.119 & 0.000 & 0.000 & 0.000 & 0.000 & 0.000 & 0.140 \\
\hline $\mathrm{F}_{10}$ & 0.000 & 0.113 & 0.000 & 0.000 & 0.000 & 0.000 & 0.000 & 0.000 & 0.000 & 0.000 \\
\hline
\end{tabular}

Primarily Normalized matrix of direct relation

\subsection{Calculation of comprehensive matrix of relations}

When normalized matrix of direct relations was calculated, using Eq. (3), comprehensive matrix of relationships can be achieved. Direct and indirect relations are shown in this matrix. This matrix has been shown in Table 5 .

$$
T=M(I-M)^{-1}
$$

Dependency scale and fluency power of each factor is calculated in order to draw cause and effective diagram. 
Table 5

Comprehensive Matrix of Relations

\begin{tabular}{llllllllllll}
\hline Factor & $\mathrm{F}_{1}$ & $\mathrm{~F}_{2}$ & $\mathrm{~F}_{3}$ & $\mathrm{~F}_{4}$ & $\mathrm{~F}_{5}$ & $\mathrm{~F}_{6}$ & $\mathrm{~F}_{7}$ & $\mathrm{~F}_{8}$ & $\mathrm{~F}_{9}$ & $\mathrm{~F}_{10}$ & $\begin{array}{l}\text { Influential } \\
\text { power }\end{array}$ \\
\hline $\mathrm{F}_{1}$ & 0.017 & 0.158 & 0.224 & 0.239 & 0.140 & 0.156 & 0.128 & 0.228 & 0.228 & 0.218 & 1.736 \\
$\mathrm{~F}_{2}$ & 0.000 & 0.044 & 0.137 & 0.024 & 0.000 & 0.019 & 0.010 & 0.098 & 0.023 & 0.125 & 0.480 \\
$\mathrm{~F}_{3}$ & 0.000 & 0.220 & 0.081 & 0.188 & 0.000 & 0.152 & 0.076 & 0.185 & 0.181 & 0.205 & 1.288 \\
$\mathrm{~F}_{4}$ & 0.000 & 0.214 & 0.194 & 0.065 & 0.000 & 0.127 & 0.020 & 0.183 & 0.190 & 0.194 & 1.187 \\
$\mathrm{~F}_{5}$ & 0.125 & 0.248 & 0.242 & 0.238 & 0.017 & 0.161 & 0.161 & 0.244 & 0.232 & 0.251 & 1.919 \\
$\mathrm{~F}_{6}$ & 0.000 & 0.180 & 0.188 & 0.178 & 0.000 & 0.045 & 0.075 & 0.149 & 0.198 & 0.192 & 1.205 \\
$\mathrm{~F}_{7}$ & 0.000 & 0.209 & 0.165 & 0.128 & 0.000 & 0.113 & 0.017 & 0.141 & 0.132 & 0.170 & 1.075 \\
$\mathrm{~F}_{8}$ & 0.000 & 0.081 & 0.011 & 0.002 & 0.000 & 0.002 & 0.001 & 0.008 & 0.002 & 0.150 & 0.257 \\
$\mathrm{~F}_{9}$ & 0.000 & 0.160 & 0.041 & 0.130 & 0.000 & 0.018 & 0.004 & 0.034 & 0.026 & 0.179 & 0.592 \\
$\mathrm{~F}_{10}$ & 0.000 & 0.118 & 0.016 & 0.003 & 0.000 & 0.002 & 0.001 & 0.011 & 0.003 & 0.014 & 0.168 \\
\hline Dependency & 0.142 & 1.632 & 1.299 & 1.195 & 0.157 & 0.795 & 0.493 & 1.281 & 1.215 & 1.697 & \\
\hline
\end{tabular}

\subsection{Drawing cause and effect diagram}

Matrix of relations prevents useful information about providing mutual relations between elements. Some of existent relations in this matrix involve very weak and unimportant ones; using threshold to omit relations considered less important ones is regarded necessary. In this research, a threshold of average matrix has been obtained. Relations between defined elements are shown in Fig. 2.

\section{Analysis of dependency scale and fluency Power}

In this part, elements and factors were arranged in 4 groups. The first group includes autonomous factors having low dependency scale and influence Power. These factors are separated from other elements. The second group includes dependent factors having low influence power but high dependency. The third group includes linkage factors. These factors have high influence power and dependency. The forth group includes independent factors. These factors have high influence power and low dependency scale. The factors having high influence power are called key factors. These factors are obviously categorized in independent or linkage groups. Their Influence power and dependency are affected in agile supply chain and are shown in Table 5. Therefore, diagram of influence power and dependency scale is constituted that has been shown in Fig. 3.

\section{Discussion and Conclusion}

Using Dematel technique and analysis influence power and dependency scale prevents useful management views. Achieved results in this project enable managers and decision makers to evaluate application of each factor. Hence, they can indirectly improve effective factors through concentration on effective factors and expending low costs.

\section{Results and Conclusion}

Results achieved from dependency scale and influence power analysis, categorize identified factors in 4 groups. In the first group that Autonomous factors are included, no factor was located. Some of factors such as customer-seller relationship, trust, reduction of cost, improvement of quality, customer's satisfaction are located in the second group. These factors have high dependency and low influence power. The third group includes other factors such as programming, forecasting, cooperative preparations, using relational and informative technical tools. These factors having high influence power and dependency scale are called linkage factors. Some of factors such as automation, unifying process, in time production and preparation for focusing unsteady market are located in the 
forth group. This analysis shows that factors in the third and forth groups have higher influence power; so it is necessary that managers and decision makers attend to it.
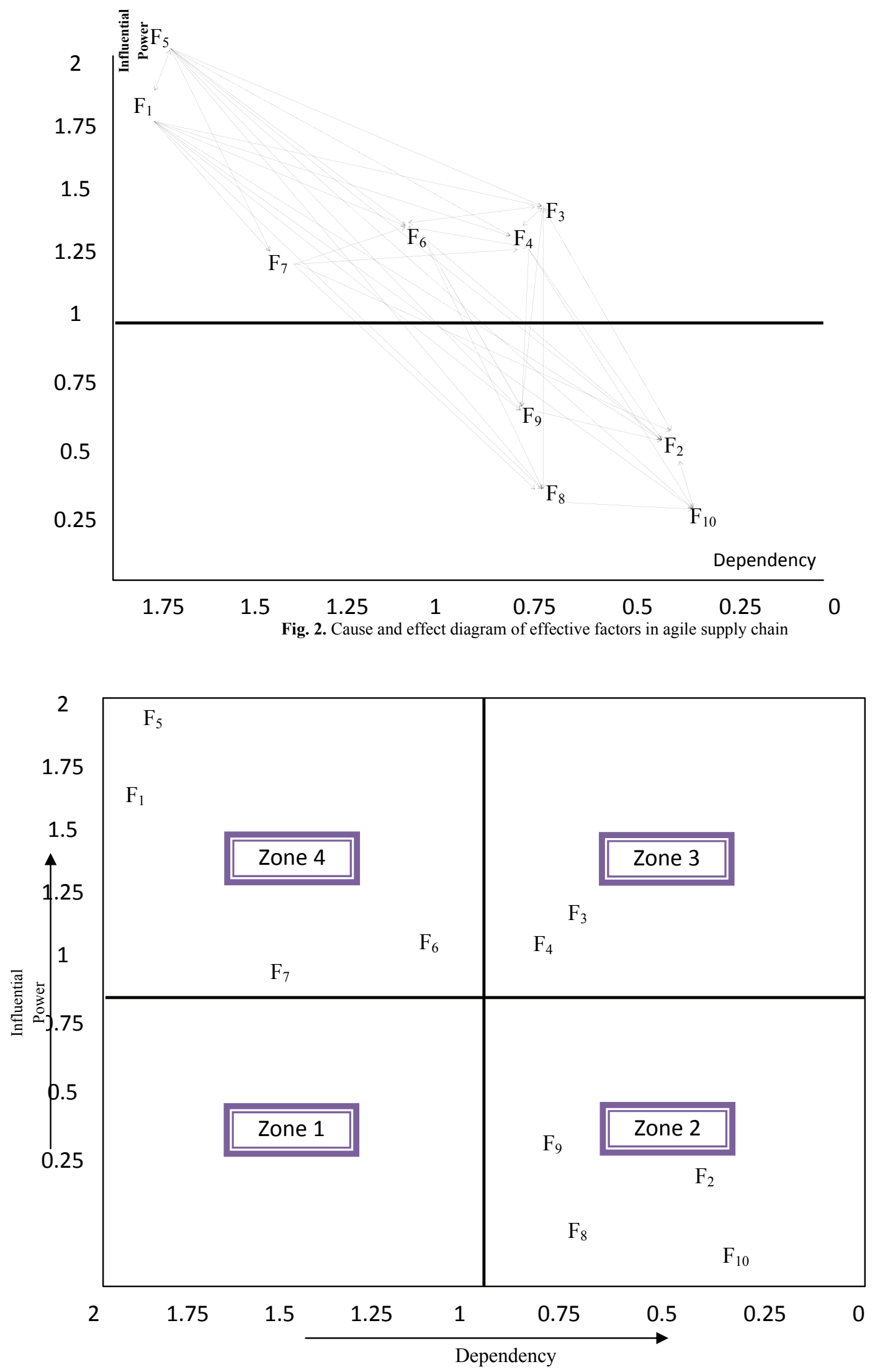

Fig. 3. Diagram of influential power- dependency 


\section{Acknowledgment}

The authors would like to thank the anonymous referees for constructive comments on earlier version of this work.

\section{References}

Abbaszadeh, M.A. Ebrahimi, M., \& Fotouhi, H. (2010). Developing a causal model of critical success factors for knowledge management implementation. International Conference on Education and Management Technology, Cairo, Egypt.

Agarwal, A., \& Shankar, R. (2003). On-line trust building in e-enabled supplies chain. Supply Chain Management: An International Journal, 8(4), 324-334.

Bultema, P. (2000). Getting the big picture on operational CRM. Proceedings of the DCI Customer Relationship Management Conference, Boston, MA, 27-29.

Cheshmberah, M., Zahedi, M. R., Hadizadeh, A., \& Tofighi, S. M. (2011). A mathematical model for optimum single-commodity distribution in the network of chain stores: a case study of food industry. Management Science Letters, 1(4), 575-582.

Chan, F.T.S., Qi, H.J., Chan, H.K., Lau, H.C.W., \& Ip, R.W.L. (2002). A conceptual model of performance measurements of supply chain. Management Decisions, 41(7), 635-642.

Dove, R., Nagel, R., Goldman, S., \& Preiss, K. (1991). 21st Century Manufacturing Enterprise Strategy: An Industry-led View. Report by the Iacocca Institute, Lehigh University, Bethlehem, PA.

Fliedner, G. (2003). CPFR: an emerging supply chain tool. Industrial Management \& Data Systems, 103(1), 14-21.

Goldman, S.L., Nagel, R.N., \& Preiss, K. (1995). Agile Competitors and Virtual Organisations. Van Nostrand Reinhold, New York, NY.

Ho, W.J. Tsai, C. Tzeng G., \& Fang, S. (2010). Combined DEMATEL technique with a novel MCDM model for exploring portfolio selection based on CAPM. Expert Systems with Applications, 42, 832-839.

Jamali, G.H. Ebrahimi, M., \& Abbaszadeh, M.A. (2010). TQM Implementation: An Investigation of Critical Success Factors, International Conference on Education and Management Technology, Cairo, Egypt.

Jharkharia, S., \& Shankar, R. (2004). IT enablement of supply chains: modeling the enablers. International Journal of Productivity and Performance Management, 53(8), 700-712.

Kumar, K., \& Brittain, J.C. (1995). Cost of quality: evaluating the health of British manufacturing industry. The TQM magazine, 7(2), 50-72.

Mason-Jones, R., \& Towill, D. R. (1999). Total cycle time compression and the agile supply chain. International Journal of Production Economics, 62, 61-73.

Milgate, M. (2001). Supply chain complexity and delivery performance: an international exploratory study. Supply Chain Management, 6(3), 106-118.

Marshall, G.W., Lassk, F.G., \& Moncrief, W.C. (2004). Salesperson job involvement: do demographic, job situational, and market variables matter?. Journal of Business \& Industrial Marketing, 19(5), 337-343.

Naylor, J.B., Naim, M.M., \& Berry, D. (1999). Leagility: interfacing the lean and agile manufacturing paradigm in the total supply chain. International Journal of Production Economics, 62, 107-118.

Pandey, V.C., \& Garg, S. (2009). Analysis of interaction among the enablers of agility in supply chain. Journal of Advances in Management Research, 6(1), 99-114.

Ravi, V., Shanker, R. \& Tiwari, M.K. (2005). Analysis of interactions among the barriers of reverse logistics. Technological Forecasting and Social Change, 72, 1011-1129. 
Rafeie rad, D., Amiri, M., Gardeshi, M., \& Siahkali Moradi, J. (2011). Application of factor analysis for agile supply chain classification: A case study on the Iranian automotive parts supplier (SAPKO). Management Science Letters, 1(4), 457-466.

Yasin, M., Correia, E., \& Lisboa, J. (2004). E profitability of customer-targeted quality improvement efforts: an empirical examination. The TQM Magazine, 16(1), 45-49.

Yusuf, Y.Y., Gunasekaran, A., E. Adeleye, E. O., \& Sivayoganathan, K. (2004). Agile supply chain capabilities: Determinants of competitive objectives. European Journal of Operational Research, 159(2), 379-392.

Shekari, H., Shirazi, S., Afshari, M. A., \& Veyseh, S. M. (2011). Analyzing the key factors affecting the green supply chain management: A case study of steel industry. Management Science Letters, $1(4), 541-550$.

Shieh, J. Wu, H., \& Huang, K. (2010). A DEMATEL Method in Identifying Key Success Factors of Hospital Service Quality. Knowledge-Based Systems, 23, 277-282.

Simchi-Levi, D., Kaminski, P., Simchi-Levi, E., \& Shankar, R. (2008). Designing and Managing Supply Chain. Tata McGraw-Hill, New Delhi.

Tsai, W.H., \& Chou, W.C. (2009). Selecting management systems for sustainable development in SMEs: A novel hybrid model based on DEMATEL, ANP, and ZOGP. Expert Systems with Applications, 36, 1444-1458.

Wu, W.W. (2008). Choosing knowledge management strategies by using a combined ANP and DEMATEL approach. Expert Systems with Applications, 35, 828-835. 